\title{
Parametric Evaluation of Digestability of Organic Fraction of Municipal Solid Waste for Biogas Production
}

\author{
Monoj K. Mondal ${ }^{* 1}$, Aparna Banerje ${ }^{2}$ \\ ${ }^{1}$ Department of Chemical Engineering and Technology, Indian Institute of Technology, Banaras Hindu \\ University, Varanasi-221005, Uttar Pradesh, India \\ e-mail: mkmondal13@yahoo.com \\ ${ }^{2}$ Department of Chemistry, Faculty of Science, Banaras Hindu University, Varanasi-221005, India \\ e-mail: aparna.banerjee1988@gmail.com
}

Cite as: Mondal, M. K., Banerjee, A., Parametric Evaluation of Digestability of Organic Fraction of Municipal Solid Waste for Biogas Production, J. sustain. dev. energy water environ. syst., 3(4), pp 416-424, 2015, DOI: http://dx.doi.org/10.13044/j.sdewes.2015.03.0031

\begin{abstract}
Municipal solid waste was collected from Varanasi’s municipal solid waste dumpsite and sorted for organic fraction present in it. Current work showed the consequences of calcium hydroxide or lime digestion on organic fraction of municipal solid waste of Varanasi, India. The organic fraction of municipal solid waste sample was digested with desired amount of calcium hydroxide. The different concentrations $(0.1,0.2$, and $0.5 \%)$ of calcium hydroxide was blended separately to substrates (10\% total solid) at $30-35{ }^{\circ} \mathrm{C}$ in 3 different beakers denoted by $\mathrm{A} 1, \mathrm{~A} 2$ and $\mathrm{A} 3$, respectively of $2 \mathrm{~L}$ capacity. Experiments of hydrolysis step were conducted on all three samples for evaluation of chemical oxygen demand, $\mathrm{pH}$ and volatile fatty acids content in sample. The parameters measured during experiments were chemical oxygen demand, biogas production, total solid, volatile solids, total Kjeldahl nitrogen and total organic carbon. Rate enhancement of anaerobic digestion and biogas production were occurred for calcium hydroxide digested samples. Therefore calcium hydroxide can be used as an effective alkali for the digestion of organic fraction of municipal solid waste.
\end{abstract}

\section{KEYWORDS}

Digestion, OFMSW, Lime, COD, Biogas.

\section{INTRODUCTION}

In most of the cities like Varanasi, the disposal of Municipal Solid Waste (MSW) is facing a serious problem due to increasing urbanization and improper treatment facilities. Unavailability of the proper treatment methods is creating serious environmental problems. To avoid such problems proper waste treatment plans have to be worked out. Since MSW generation are rapidly increasing, thus provoking huge waste disposal problems [1]. The government is mainly concerned with the incorporation of solutions for the treatment of such complex wastes [2]. Among the existing treatment methods, one of the most attractive approaches for the treatment of organic waste can be the anaerobic digestion. Anaerobic digestion can be useful as a disposal route as well as a source of alternative energy [3]. Extensive specific recent literature is available on the digestion of Organic Fraction of Municipal Solid Waste (OFMSW) and organic matter from different sources that is presented as a suitable technology used for a treatment of organic wastes and production of energy from combustion of biogas, as well as greenhouse gases reduction [4]. Co-digestion is usually performed because of the problems herein. The

\footnotetext{
* Corresponding author
} 
main issue for the co-digestion process lies in balancing several parameters in the co-substrate mixture viz., macro-and micronutrients, carbon to nitrogen ratio, $\mathrm{pH}$, inhibitors/toxic compounds, biodegradable organic matter and dry matter [5]. Microbial mediated transformation of organic fraction of the solid wastes has been accepted as a valuable resource that can be renewed into useful products [6]. Anaerobic digestion is a biological conversion without oxygen as an external electron acceptor as in aerobic processes or nitrate/sulphate as in anoxic processes. During this process successive oxidation and reduction of the organic carbon takes place. A wide range of micro-organisms acts as catalyst in the absence of oxygen and as a resultant the most oxidized state $\left(\mathrm{CO}_{2}\right)$ and most reduced state $\left(\mathrm{CH}_{4}\right)$ of organic carbon are formed respectively [7]. Function of the methanogenic bacteria has been observed to be highly sensitive to the levels of free ammonia generated during anaerobic degradation of nitrogen rich protein components [8]. The specific activity of methanogen bacteria is inversely proportional to the free ammonia concentration [9]. The popularity of the anaerobic treatment is not as widespread as the aerobic process, particularly due to the longer requirement of the time to reach bio-stabilization [10]. Still anaerobic processes are considered as a feasible technology for the treatment of MSW and simultaneous production of a renewable energy, due to its low energy requirement for operation and low biomass production as compared to aerobic process [11]. During the anaerobic process, sealed environment is used. The leakage of methane and other gases is not possible, making the whole process environment friendly [12]. Also the release of carbon-neutral carbon dioxide due to the burning of the methane has no net effect on atmospheric carbon dioxide and other greenhouse gases [13]. Significantly these benefits of anaerobic treatment over other processes make it more vital for the exploration by scientists.

Further, methane and hydrogen are considered as potential fuels and comparatively cleaner than fossil fuel [14]. Thus environmental pollution can be controlled by anaerobic digestion process and at the same time it can act as a source of biogas and organic fertilizer. The gaseous mixture produced is named as biogas and the whole anaerobic digestion process is termed as biogas process [15].

Furthermore some of the limitations of the anaerobic process such as long retention times and low removal efficiencies of organic compounds are due to the complex structure of the organic matters [16]. These effects are more pronounced in the case of biodegradation of solid waste as compared to the liquid waste. Anaerobic digestion of complex organic material could be described as a sequential process that involves the steps of hydrolysis, acidogenesis, acetogenesis and methanogenesis [17]. During the anaerobic digestion of complex organic matter the hydrolysis is the first and often rate-limiting step. It is an established fact that the rate limiting step in the anaerobic digestion process for solid wastes is the hydrolysis of the complex organic matter to soluble components [18].

So these problems can be encountered by consequently doing some physical, chemical or biological pre-treatment of the solid wastes [19]. Previous studies have shown that alkali pre-treatment is one of the best methods for the enhancement of the rate of anaerobic digestion [20,21]. Although sodium hydroxide $(\mathrm{NaOH})$ is the best known chemical for this purpose [22] but it is quite expensive, hence increases the pre-treatment cost whereas calcium hydroxide $\left(\mathrm{Ca}(\mathrm{OH})_{2}\right)$ is much cheaper and easily available. Thus lime pre-treatment might be an economical option for anaerobic digestion of Organic Fraction of Municipal Solid Waste (OFMSW). The main objective of this experiment is to study the effect of lime on anaerobic digestion of MSW, especially on its organic fractions. 


\section{MATERIALS AND METHODS}

\section{Feed stock preparation and analysis}

For this study, samples from dumping sites of Varanasi were collected and separated into various fractions like biodegradables, combustibles and inert. A $10 \mathrm{~kg}$ sample of biodegradables was placed in nylon bag and brought to the laboratory, where the OFMSW was mechanically liquidized with the help of a mixer-grinder and mixed with water to obtain a concentration of $10 \%$ Total Solids (TS). The characteristics of OFMSW from all of the analysis are shown in Table 1.

Table 1. Characteristics of OFMSW used in the experiment

\begin{tabular}{cc}
\hline Parameters & Values obtained \\
\hline Moisture Content [\%] & 79 \\
Total Solid [\%] & 20.2 \\
Volatile Solid [\% of TS] & 83.4 \\
pH & 6.2 \\
t COD [mg/l] & 55,400 \\
TOC solid [mg/l] & 38.84 \\
TKN solid [mg/l] & 1.34 \\
\hline
\end{tabular}

\section{Pre- treatment conditions}

Three different amounts $(0.1,0.2,0.5 \%)$ of $\mathrm{Ca}(\mathrm{OH})_{2}$ was blended to substrates $(10 \%$ TS) at $30-35{ }^{\circ} \mathrm{C}$ separately in 3 different conical flasks A1, A2, A3 of 2 L capacity each. A fourth flask was kept as a control without adding any $\mathrm{Ca}(\mathrm{OH})_{2}$. Experiments were conducted on all four samples by evaluating COD solubilisation. It was transferred for methanogenesis, on the $6^{\text {th }}$ day after adjusting the $\mathrm{pH}$ to 6.8-7.2. Cow dung was added as inoculums in the methanogenesis step ( $15 \%$ by weight). The gas production was measured using a graduated $1,000 \mathrm{ml}$ burette filled with water (water displacement method). The amount of biogas produced was observed in all four cases. The biogas yield was measured with the help of a Gas Chromatograph (Nucon 5765, New Delhi, India) equipped with a thermal conductivity detector. The helium was used as carrier gas at a flow rate of $30 \mathrm{ml} / \mathrm{min}$. The injector, column and detector temperature were kept constant at 363,393 and $393 \mathrm{~K}$, respectively. The biogas production potential of cow dung was deducted from the total biogas to get the actual yield of biogas from OFMSW. After completion of experimental run (no biogas yield), the bio-digested sludge was filtered and analysed for Total Solid (TS), Total Organic Carbon (TOC), Total Kjeldahl Nitrogen (TKN) and Volatile Solids (VS). The methodology adapted for experimentation to analyse the sample in shown in Figure 1.

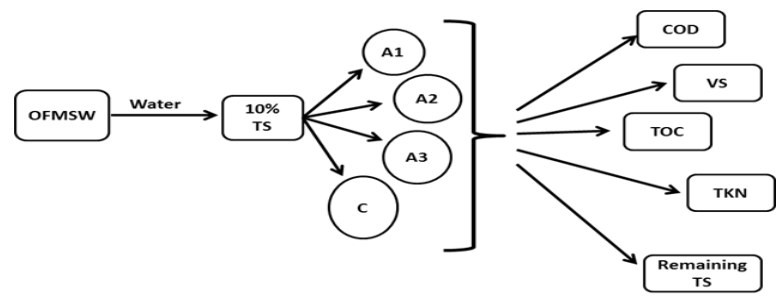

Figure 1. Experimental methodology adopted for measuring various important parameters [A1: $10 \% \mathrm{TS}+0.1 \% \mathrm{Ca}(\mathrm{OH})_{2}, \mathrm{~A} 2: 10 \% \mathrm{TS}+0.2 \% \mathrm{Ca}(\mathrm{OH})_{2}, \mathrm{~A} 3: 10 \% \mathrm{TS}+0.5 \% \mathrm{Ca}(\mathrm{OH})_{2}, \mathrm{C}: 10 \%$ TS (control)] 


\section{Analytical methods}

All analyses were performed for Chemical Oxygen Demand (COD) determination using potassium dichromate-ferrous ammonium sulphate, Soluble Chemical Oxygen Demand (SCOD), Total Solids (TS) after heating the sample at $105-110{ }^{\circ} \mathrm{C}$ for $5 \mathrm{~h}$, and Volatile Solids (VS) content of the sample using muffle furnace maintained at $925^{\circ} \mathrm{C}$ for $1 \mathrm{~h}$ by following standard test methods of American Public Health Association [23]. TOC was determined using potassium dichromate-ferrous sulphate in accordance to Walkley-Black method [24] and TKN was determined using sulphuric acid digestion as per the standard Kjeldahl nitrogen estimation method [25]. All experiments were repeated three times to justify the data.

\section{RESULTS AND DISCUSSION}

The influence of $\mathrm{Ca}(\mathrm{OH})_{2}$ addition on $\mathrm{COD}$ solubilisation, biogas production, reduction in TS, VS, TKN and TOC were evaluated to interpret the results in context of biogas yield. Figure 2 shows that at initial days the value of COD increases and after certain value it starts decreasing. This effect is seen more for the samples A1, A2, A3 having $0.1,0.2,0.5 \% \mathrm{Ca}(\mathrm{OH})_{2}$, respectively than the sample $\mathrm{C}$ which is the control sample. In Table 2 it is evident that the TOC and TKN content of all samples are decreasing irrespective of $\mathrm{Ca}(\mathrm{OH})_{2}$ added to the sample. The final TOC and TKN content are minimum for the sample having $0.2 \% \mathrm{Ca}(\mathrm{OH})_{2}$ (sample A2).

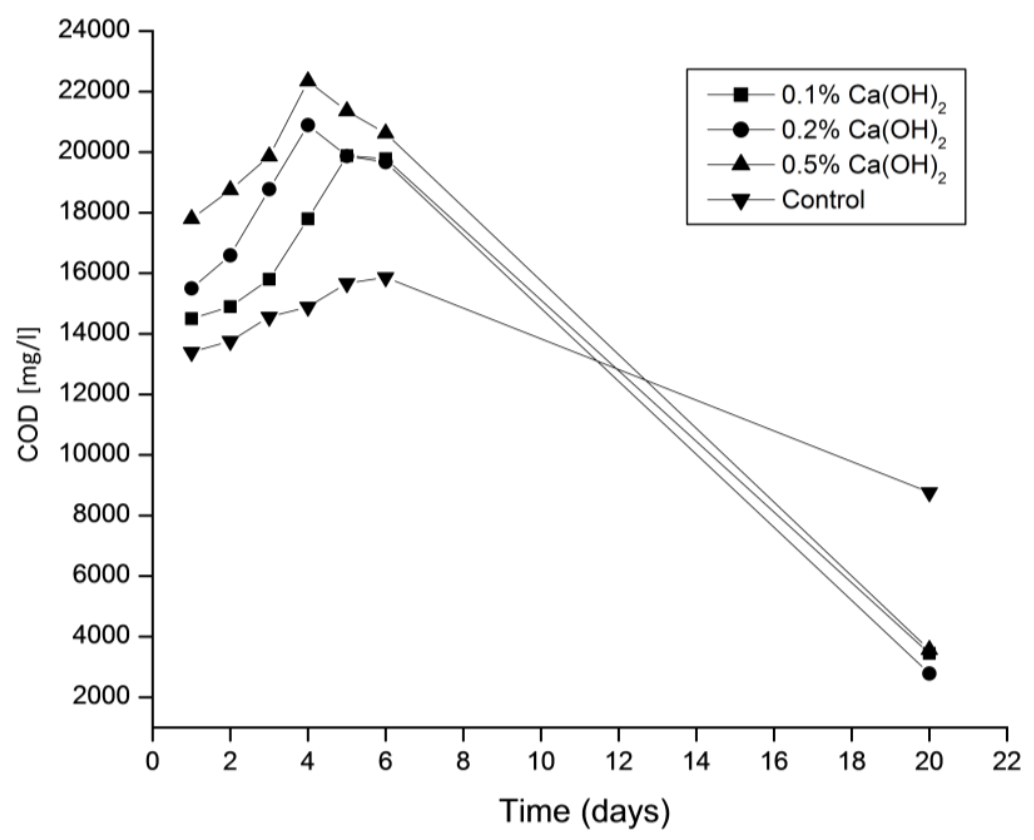

Figure 2. Variation of COD values with different concentrations of $\mathrm{Ca}(\mathrm{OH})_{2}$ in hydrolysis

Table 2. Values of TOC and TKN for different samples

\begin{tabular}{cccccc}
\hline Samples & $\begin{array}{c}\mathrm{Ca}(\mathrm{OH})_{2} \\
\text { added [\%] }\end{array}$ & $\begin{array}{c}\text { TOC } \\
\text { (initial) }\end{array}$ & $\begin{array}{c}\text { TOC } \\
\text { (final) }\end{array}$ & $\begin{array}{c}\text { TKN } \\
\text { (initial) }\end{array}$ & $\begin{array}{c}\text { TKN } \\
\text { (final) }\end{array}$ \\
\hline A1 & 0.1 & 38.84 & 25.85 & 1.34 & 1.24 \\
A2 & 0.2 & 38.84 & 19.76 & 1.34 & 1.16 \\
A3 & 0.5 & 38.84 & 21.90 & 1.34 & 1.19 \\
C & 0.0 & 38.84 & 29.43 & 1.34 & 1.30 \\
\hline
\end{tabular}


It is further observed that there is reduction in TS and VS for all the samples with or without the addition of $\mathrm{Ca}(\mathrm{OH})_{2}$ and the maximum reduction is observed for the sample A2 having $0.2 \% \mathrm{Ca}(\mathrm{OH})_{2}$ (Figures 3-4, Table 3). Further maximum total biogas production is shown by the sample A2 (Figure 5).

Table 3. Values of TS, VS, and Biogas production for different samples

\begin{tabular}{ccccc}
\hline Samples & $\begin{array}{c}\mathrm{Ca}(\mathrm{OH})_{2} \\
\text { added [\%] }\end{array}$ & $\begin{array}{c}\text { Reduction in } \\
\text { TS [\%] }\end{array}$ & $\begin{array}{c}\text { Reduction } \\
\text { in VS [\%] }\end{array}$ & $\begin{array}{c}\text { Total biogas } \\
{\left[\mathrm{Nm}^{3} / \mathrm{kg}\right]}\end{array}$ \\
\hline A1 & 0.1 & 25 & 34 & 0.20 \\
A2 & 0.2 & 35 & 43 & 0.25 \\
A3 & 0.5 & 30 & 40 & 0.20 \\
C & 0.0 & 15 & 25 & 0.15 \\
\hline
\end{tabular}

An increment in SCOD value was observed when the $\mathrm{Ca}(\mathrm{OH})_{2}$ concentration was increased. It can be visualized by seeing the data of SCOD values on the $4^{\text {th }}$ day for the samples A1, A2, A3 are 17,800, 20,890, 22,340 mg/l, respectively, as compared to the control sample whose SCOD value is $14,890 \mathrm{mg} / \mathrm{l}$. Also there is sudden increase in the $\mathrm{pH}$ of the samples due to addition of $\mathrm{Ca}(\mathrm{OH})_{2}$ then gradual decrease in $\mathrm{pH}$ was noticed. Similar results were also reported earlier [26]. Initially an increment was shown followed by the decrease in the SCOD value was observed, which can be due to the formation of non-soluble complexes, because of which the hydrolysis process is hindered.

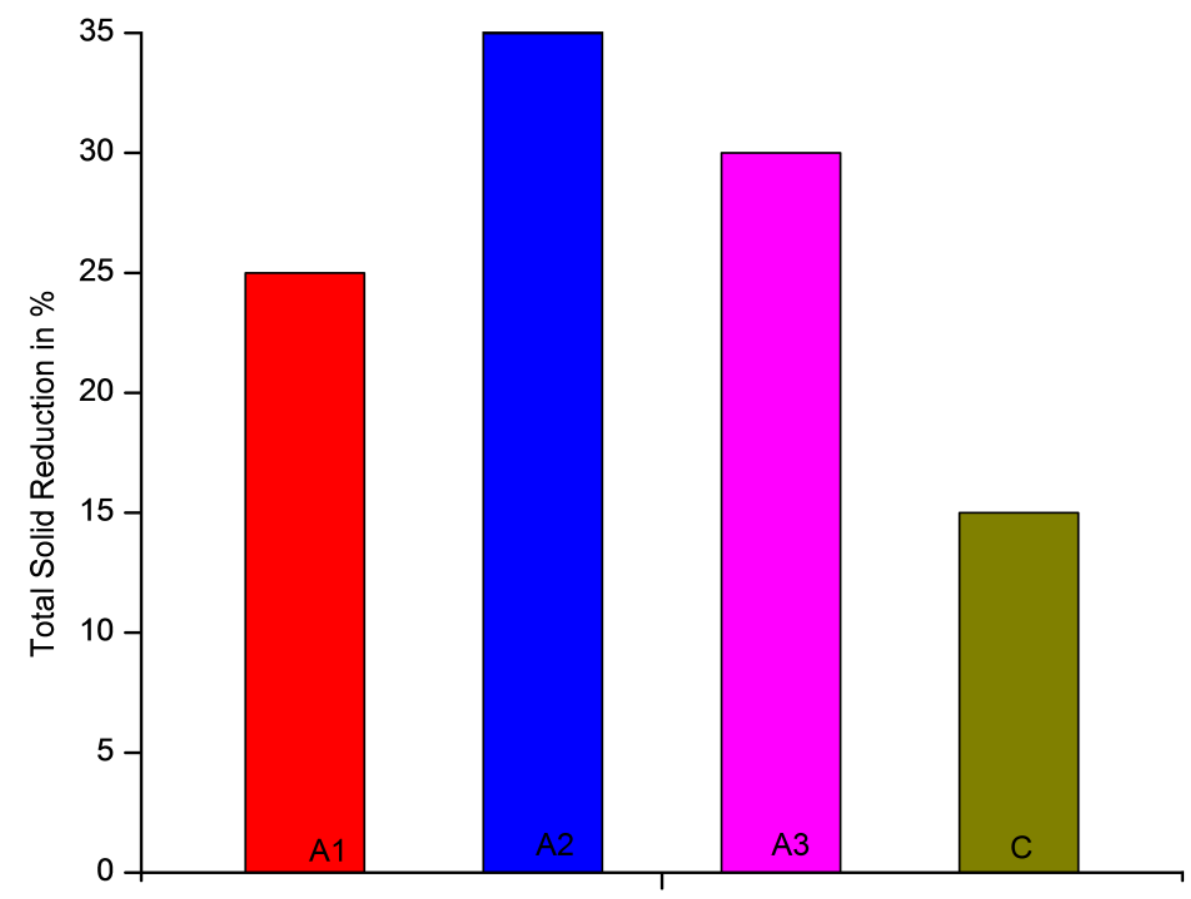

Figure 3. Total solid reduction with different concentrations of $\mathrm{Ca}(\mathrm{OH})_{2}$ during methanogenesis

Hence it can be seen that alkali pre-treatment has a positive effect on digestion of OFMSW, since it causes the increase in the SCOD value and also increases the surface area of complex organic matter by swelling [27]. Due to high surface area, these become more susceptible to the enzymatic attack by microorganisms, and the digestion process is enhanced further. 


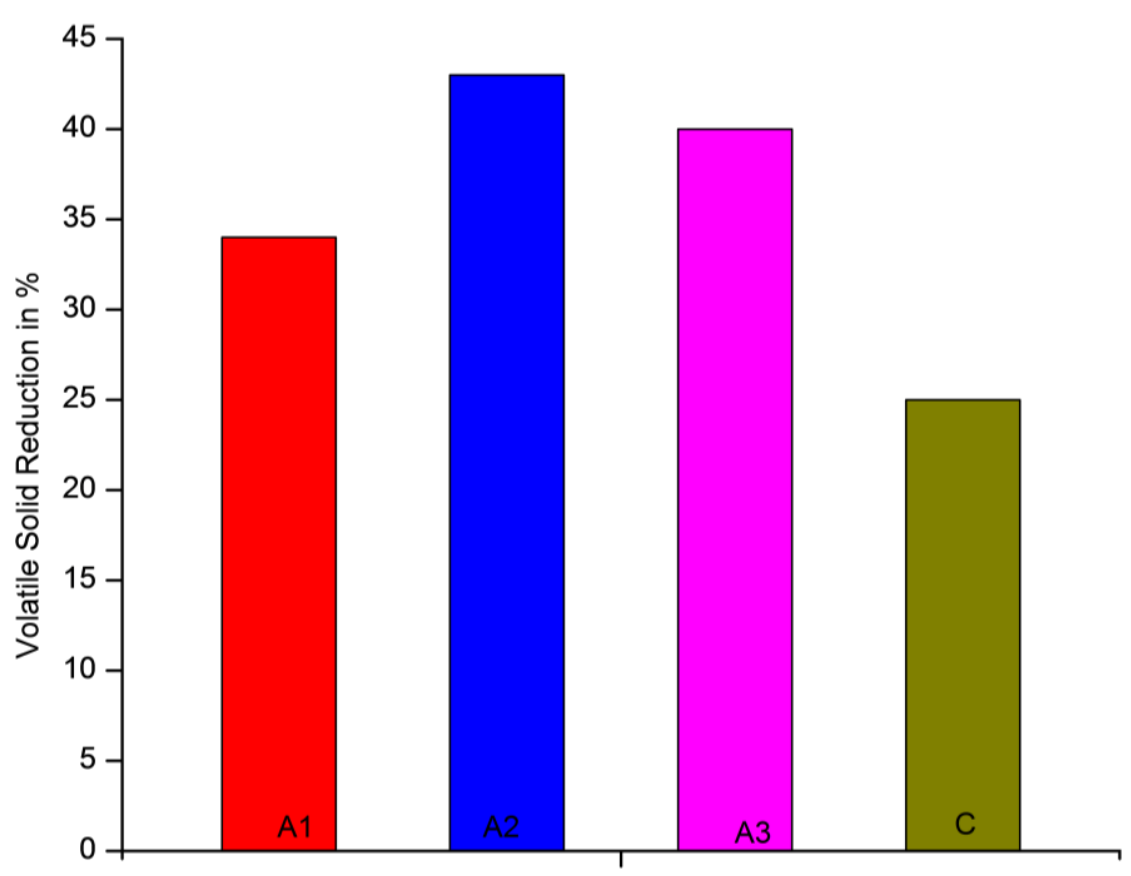

Figure 4. Total VS reduction with different concentrations of $\mathrm{Ca}(\mathrm{OH})_{2}$ methanogenesis

Similar reasons can also be given for biogas production. The biogas production is higher for the pre-treated samples than the control having no addition of $\mathrm{Ca}(\mathrm{OH})_{2}$, suggesting that pre-treatment enhances the rate of anaerobic digestion by hydrolysing the complex organic matter to soluble components and also by increasing the availability of the surface area for enzymatic action as a result of fibre swelling [22].

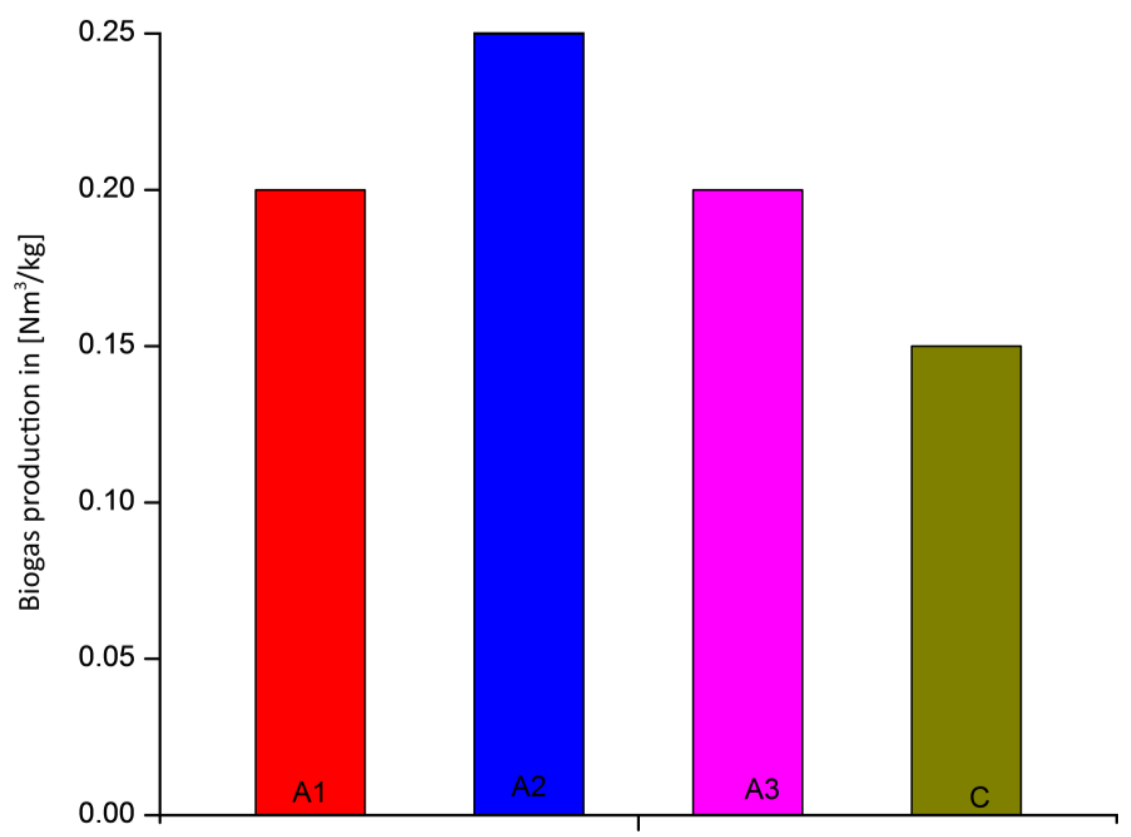

Figure 5. Total biogas production in $\mathrm{Nm}^{3} / \mathrm{kg}$ with different concentrations of $\mathrm{Ca}(\mathrm{OH})_{2}$

\section{CONCLUSIONS}

Initially COD value increases with time and reaches a maximum value and after this it starts decreasing. Both TOC and TKN content of the samples at the end are less than those of initial values. The maximum biogas yield was found to be $0.25 \mathrm{Nm}^{3} / \mathrm{kg}$ for $0.2 \%$ 
$\mathrm{Ca}(\mathrm{OH})_{2}$ added sample. The results of present research work suggest that under the appropriate alkali treatment, complex organic matter becomes more biodegradable by roughly changing its chemical structure to simpler soluble organics. So this methodology can be used effectively for the sustainable management of the MSW in terms of resource generation as biogas and thus reducing its disposal problem.

\section{ACKNOWLEDGEMENT}

This research is a part of project funded by DST, Ministry of Science and Technology, Government of India, New Delhi (Order No. SR/FTP/CS-75/2006).

\section{REFERENCES}

1. Pavlostasthis, S. G. and Gosset, J. M., Modelling Alkali Consumption and Digestibility Improvement from Alkaline Treatment of Wheat Straw, Biotechnol.

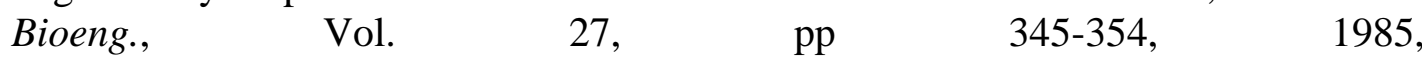
http://dx.doi.org/10.1002/bit.260270320

2. Delgenes, J. P., Penaud, V., Torrijos, M. and Moletta, R., Thermochemical Pre-treatment of an Industrial Microbial Biomass: Effect of Sodium Hydroxide addition on COD Solubilisation, Anaerobic Biodegradability and Generation of Soluble Inhibitory Compounds, In: Proceeding II international symposium on anaerobic digestion of solid waste, Barcelona, Spain, 1999.

3. Lee, M., Hidaka, T., Hagiwara, W. and Tsuno, H., Comparative Performance and Microbial Diversity of Hyperthermophiclic and Thermophilic Co-digestion of Kitchen Garbage and Excess Sludge, Bioresour. Technol., Vol. 100, pp 578-585, 2009, http://dx.doi.org/10.1016/j.biortech.2008.06.063

4. Mata-Alvarez, J., Dosta, J., Romero-Güiza, M. S., Fonoll, X., Peces, M. and Astals, S., A Critical Review on Anaerobic Co-digestion Achievements between 2010 and 2013, Renew. Sust. Energ. Rev., Vol. 36, pp 412-427, 2014, http://dx.doi.org/10.1016/j.rser.2014.04.039

5. Álvarez, J. A., Otero, L. and Lema, J. M., A Methodology for Optimizing Feed Composition for Anaerobic Co-digestion of Agro-industrial Wastes, Bioresour. Technol., Vol. 101, pp 1153-1158, 2010, http://dx.doi.org/10.1016/j.biortech.2009.09.061

6. Lesteur, M., Bellon-Maurel, V., Gonzalez, C., Latrille, E., Roger, J. M., Junqua, G. and Steyer, J. P., Alternative Methods for Determining Anaerobic Biodegradability: a Review, Process Biochem., Vol. 45, pp 431-440, 2010, http://dx.doi.org/10.1016/j.procbio.2009.11.018

7. McInerney, M. J., Bryant, M. P. and Stafford D. A., Metabolic Stages and Energetics of Microbial Anaerobic Digestion, In: Stafford DA, Wheatley BI \& Hudges DE (Eds) Anaerobic Digestion, Applied Science Ltd, London, pp 91-98, 1980.

8. Fountoulakis, M. S., Drakopoulou, S., Terzakis, S., Georgaki, E. and Manios, T., Potential for Methane Production from typical Mediterranean Agro-industrial by-products, Biomass Bioenerg., Vol. 32, pp 155-161, 2008, http://dx.doi.org/10.1016/j.biombioe.2007.09.002

9. Chen, Y., Cheng, J. J. and Creamer, K. S., Inhibition of Anaerobic Digestion Process: a Review, Bioresour. Technol., Vol. 99, pp 4044-4064, 2008, http://dx.doi.org/10.1016/j.biortech.2007.01.057

10. Fernandez, J., Perez, M. and Romero, L. I., Kinetics of Mesophilic Anaerobic Digestion of the Organic Fraction of Municipal Solid Waste: Influence of Initial Total Solid Concentration, Bioresour. Technol., Vol. 101, pp 6322-6328, 2010, http://dx.doi.org/10.1016/j.biortech.2010.03.046 
11. Wang, Q., Kuninobu, M., Kakimoto, K., Ogawa, H. I. and Kato, Y., Upgrading of Anaerobic Digestion of Waste activated Sludge by Ultrasonic pretreatment, Bioresour. Technol., Vol. 68, pp 309-313, 1999, http://dx.doi.org/10.1016/S0960-8524(98)00155-2

12. Ward, A. J., Hobbs, P. J., Holliman, P. J. and Jones, D. L., Optimization of the Anaerobic Digestion of Agricultural Resources, Bioresour. Technol., Vol. 99, pp 7928-7940, 2008, http://dx.doi.org/10.1016/j.biortech.2008.02.044

13. Khalid, A., Arshad, M., Anjum, M., Mahmood, T. and Dawson, L., The Anaerobic Digestion of Solid Organic Waste, Waste Manage., Vol. 31, pp 1737-1744, 2011.

14. Jingura, R. M. and Matengaifa, R., Optimization of Biogas production by Anaerobic Digestion for Sustainable Energy development in Zimbabwe, Renew. Sust. Energy Rev., Vol. 13, pp 1116-1120, 2009, http://dx.doi.org/10.1016/j.rser.2007.06.015

15. Kiran, E. U., Trzcinski, A. P., Jern, N. W. and Liu, Y., Bioconversion of Food Waste to Energy: a Review, Fuel, Vol. 134, pp 389-399, 2014, http://dx.doi.org/10.1016/j.fuel.2014.05.074

16. Park, C., Lee, C., Kim, S., Chen, Y. and Chase, H. A., Upgrading of Anaerobic Digestion by Incorporating Two different Hydrolysis Processes, J. Biosci. Bioeng., Vol. 100, pp 164-167, 2005, http://dx.doi.org/10.1263/jbb.100.164

17. Angelidaki, I. and Sanders, W., Assessment of the Anaerobic Biodegradability of Macropollutants, Rev. Environ. Sci. Biotechnol., Vol. 3, pp 117-129, 2004, http://dx.doi.org/10.1007/s11157-004-2502-3

18. Dasgupta, B., Upender, S. and Mondal, M. K., Composition and Characterization of Simulated Putrescible Garbage, Biomass Bioenerg., Vol. 35, pp 4376-4380, 2011, http://dx.doi.org/10.1016/j.biombioe.2011.08.008

19. Charles, W., Walker, L. and Cord-Ruwisch, R., Effect of Pre-aeration and Inoculum on the Start-up of Batch Thermophilic Anaerobic Digestion of Municipal Solid Waste, Bioresour. Technol., Vol. 100, pp 2329-2335, 2009, http://dx.doi.org/10.1016/j.biortech.2008.11.051

20. Torres, M. L. and de Llorens, M. C. E., Effect of Alkaline Pretreatment on Anaerobic Digestion of Solid Wastes, Waste Manage., Vol. 28, pp 2229-2234, 2008, http://dx.doi.org/10.1016/j.wasman.2007.10.006

21. Rodri'guez-Va'zquez, R., Villanueva-Ventura, G. and Rios-Leal, E., Sugarcane Bagasse Pith Dry Pre- treatment for Single Cell Protein Production, Bioresour. Technol., Vol. 39, pp 17-22, 1992, http://dx.doi.org/10.1016/0960-8524(92)90051-X

22. Chulhwan, P., Chunyeon, L., Sangyong, K., Yu, C. and Howard, C. H., Upgrading of Anaerobic Digestion by Incorporating two different Hydrolysis Processes, J. Biosci. Bioeng., Vol. 100, pp 164-167, 2005, http://dx.doi.org/10.1263/jbb.100.164

23. APHA, Standard methods for the examination of water and waste water, $14^{\text {th }}$ edition, Washington, DC: APHA, AWWA and WEF, 1976.

24. Walkley, A. and Black, I. A., An Examination of Degtjareff Method for determining Soil Organic Matter and a Proposed Modification of the Chromic Acid Titration Method, Soil Sci., Vol. 37, pp 1934, http://dx.doi.org/10.1097/00010694-193401000-00003

25. Cheung, K. C., Chu, L. M. and Wong, M. H., Ammonia stripping as a Pre-treatment for Landfill Leachate, Water Air Soil Pollut., Vol. 94, pp 209-221, 1997, http://dx.doi.org/10.1007/BF02407103

26. Rajan, R. V., Lin, J. G. and Ray, B. T., Low-level Chemical Pre-treatment for Enhanced Sludge Solubilisation, J. Water Pollut. Feder., Vol. 64, pp 1678-1683, 1989.

27. Espinosa, M. C., Lo'pez, M., Montalvo, S., Escobedo, R., Ru1'z, M. and Correa, O., Chemical Solubilisation and Anaerobic Treatment of Sewage Sludge, In: Proceeding 
earth conference on biomass for energy, development and the environment, Havana, Cuba, 1995.

Paper submitted: 25.03.2015

Paper revised: 27.05.2015

Paper accepted: 16.06.2015 